\title{
Leokadia Styrcz-Przebinda*
}

KARPACKA PAŃSTWOWA UCZELNIA W KROŚNIE

ORCID 0000-0003-4505-2472

\section{Grigorij Krużkow- poezji anglojezycznej ttumacz niestrudzony}

Przedstawiane teksty autorstwa Grigorija Krużkowa pochodzą z jego książki Księżyc i dyskobol. O poezji i przektadzie poetyckim (2012)1. Z całego jej bogactwa wybrałam do tłumaczenia cykl trzech esejów o naturze przekładu poetyckiego oraz recenzję angielskich tłumaczeń Puszkinowskiego Eugeniusza Oniegina ${ }^{2}$. Już pierwszy z prezentowanych tu esejów, Przektad a mechanika kwantowa, daje wyobrażenie o rozpiętości zainteresowań autora, prowadzącego najpierw przez wiele lat badania w obrębie nauk ścisłych (fizyka wysokich energii), by później, po doktoracie z filologii na Uniwersytecie Columbia w Nowym Jorku, poświęcić się całkowicie literaturze i przekładowi, zarówno od strony teoretycznej, jak i praktycznej. Warto dodać, że kwantową naturę poezji i jej przekładu dostrzegali wcześniej tacy poeci jak Wystan Hugh Auden

1 Г. Кружков, Луна и дискобол. О поэзии и поэтическом переводе, Издательство РГГУ, Москва 2012.

2 Dwa z nich były przeze mnie publikowane w piśmie „Przekładaniec” 35/20I7, teraz jednak widać, jak bardzo się uzupełniają, tworząc trzyczęściowy cykl. Czwarty esej dołączyłam głównie ze względu na postać Vladimira Nabokova i jego udział w burzliwej kiedyś dyskusji o metodzie tłumaczenia klasyki, w tym Eugeniusza Oniegina. Twórcy temu poświęciłam wcześniej dwa własne artykuły.

\footnotetext{
* Dr Leokadia Styrcz-Przebinda, filolog - slawistka i polonistka. Studia slawistyczne na Uniwersytecie Jagiellońskim, doktorat z językoznawstwa w Instytucie Języka Polskiego PAN. Obecnie adiunkt w Karpackiej Państwowej Uczelni im. Stanisława Pigonia w Krośnie. Zainteresowania badawcze: komparatystyka slawistyczna ze szczególnym uwzględnieniem konceptów lingwokulturowych języka rosyjskiego oraz literatura z zagadnieniami przekła$\mathrm{du}$ - w teorii i w praktyce. Współautorka rodzinnego tłumaczenia Przebindów arcydzieła Michaiła Bułhakowa Mistrz i Matgorzata (2016). Opublikowała studium porównawcze 'Tęsknota', 'smutek', 'żal' w dwóch rosyjskich przektadach „Pana Tadeusza”. Ostatnio pisała o niezbadanych dotąd związkach Mirona Białoszewskiego z Podkarpaciem (Podkarpaciem urzeczony. Ziemia krośnieńska i jej okolice w zaczarowanym kręgu poezji Biatoszewskiego).
} 
czy Osip Mandelsztam. Podobne niespodzianki czekają nas ciągle podczas lektury Krużkowa i to właśnie czyni ją tak atrakcyjną, zwłaszcza dla filologa z komparatystycznymi ambicjami. W jednym z wywiadów autor mówił:

Jestem przekonany, że wszyscy poeci myślą w podobny sposób, zatem najlepszy komentarz do wierszy jednego poety stanowią wiersze innego. Ujawnia się to w sposób najciekawszy w przypadku poetów piszących w różnych językach. Dzięki wieloletniemu czytaniu angielskiej poezji, wyrobiłem sobie swego rodzaju podwójny odbiór - jednoczesne widzenie jednej literatury przez pryzmat drugiej. Siłą rzeczy, trzeba było stać się komparatystą ${ }^{3}$.

Swoje tezy w obrębie teorii przekładu Krużkow nie tylko popiera licznymi przykładami tłumaczeń angielskich poetów, ale pokazuje od razu paralele w twórczości autorów rosyjskich. Czytelnik niejednokrotnie jest zaskoczony ich uderzającą trafnością, wiedząc też, że wcale nie byłyby one łatwe do samodzielnego odkrycia. Zestawianie wierszy należących do dwóch odrębnych etapów twórczości Williama Butlera Yeatsa, irlandzkiego noblisty (I923), z odpowiednimi utworami Nikołaja Gumilowa, Anny Achmatowej, Aleksandra Błoka, Osipa Mandelsztama, Borysa Pasternaka pozwala także rzucić nowe światło na przynależność poszczególnych poetów do symbolizmu, akmeizmu, czy też ogólniej - neoromantyzmu. Tę właśnie wykrytą przez siebie ponadnarodową łączność autorów określa badacz mianem communio poetarum. Udowadnia on, że poezja w Rosji XX wieku przeszła de facto taką samą drogę, jaka stała się udziałem Yeatsa - z uwzględnieniem oczywiście wpływu pierwszej wojny światowej, rewolucji październikowej i ówczesnych zamieszek społecznych. Wczesny Yeats jest rówieśnikiem rosyjskich symbolistów, późny zaś - oberiutów, takich jak Konstanty Waginow czy Aleksander Wwiedienski.

W Roku Szekspirowskim 2016 Krużkow został laureatem Nagrody Sołżenicyna, przyznawanej dorocznie przez moskiewski Dom Emigracji Rosyjskiej, z Natalią Sołżenicynową na czele. Na łamach dziennika „Rossijskaja Gazieta” tak wyjaśniał, co skłoniło go do przełożenia na nowo Króla Leara:

Trud podjęty przeze mnie wynika z wyjątkowego, namiętnego wręcz uwielbienia dla tej sztuki [...], która, podobnie jak Burza, jest tragedią odejścia, pożegnania. Oba te dramaty mają ze sobą wiele wspólnego. W ich centrum bowiem stoi potężny starzec, król albo czarodziej, który rezygnuje ze swej mocy [...], aby przyjąć przeznaczony mu los zwykłego śmiertelnika. Lew Tołstoj, jak wiadomo, ostro krytykował Króla Leara [...], by jednak pod koniec życia prawie dosłownie powtórzyć los tego bohatera ${ }^{4}$.

3 О. Балла-Гертман, Григорий Кружков. Переводесть стремление окончательно понять, URL: http://textura.club/perevod-est-stremlenie-okonchatelno-ponyat/ (dostęp I.o6.202I). Wszystkie tłumaczenia cytatów moje - L. S-P.

4 Krużkow przetłumaczył na nowo obie te szekspirowskie sztuki. Szerzej, patrz: П. Басинский, Переводчик Григорий Кружков рассказал об особенностях своей профессии, URL: https:// 
Ciekawy jest dla nas fakt, że Grigorij Krużkow ma w dorobku poetyckim wiersz o Polsce ${ }^{5}$ motywem czerwonych maków, jawnie odsyłającym do żołnierskiej pieśni Czerwone maki na Monte Cassino. Autor potwierdził to odniesienie w korespondencji ze mną w roku 20I6, pisząc o swym wielkim sentymencie do naszej ojczyzny, który podzielało jeszcze w latach siedemdziesiątych wielu ówczesnych przedstawicieli rosyjskiej inteligencji twórczej. Byli oni także często tłumaczami, jak - przede wszystkim - Josif Brodski ${ }^{6}$, a z mniej u nas znanych - Borys Słucki, Dawid Samojłow i Borys Dubin 7 . Ten ostatni przełożył bardzo dużo utworów z literatury francuskiej, hiszpańskiej, latynoamerykańskiej, ale także i polskiej. Był zapalonym tłumaczem Brunona Szulca i Czesława Miłosza, a także, co wyjątkowo ciekawe, Janusza Szubera, poety z Sanoka. Pierwszym impulsem do nauki języka polskiego stało się dla niego pragnienie przełożenia wiersza Przypowieść Krzysztofa Kamila Baczyńskiego, pisanego podczas Powstania Warszawskiego. Przypomniał o tym ostatnio w Rosji Nikita Jelisiejew, dyrektor Państwowej Biblioteki Rosyjskiej im. Sałtykowa-Szczedrina w Petersburgu, znany skądinąd krytyk i tłumacz:

Dla inteligencji rosyjskiej, od lat pięćdziesiątych do siedemdziesiątych, Polska była oknem na świat europejskiej kultury. W Polsce jeszcze socjalistycznej publikowane było to, co nigdy i w żadnej postaci w Związku Radzieckim publikowane być nie mogło. Josif Brodski opanował polski język, by móc czytać Becketa i Ionesco, wydawanych w Warszawie. Całkiem możliwe, że ktoś inny chciał się nauczyć tego języka, aby przeczytać wydaną w bratnim kraju Lolitę, w dodatku ze wspaniałą przedmową Stanisława Lema. A Borys Dubin nauczył się polskiego, żeby najpierw pojąć, a potem przetłumaczyć wspomniany wiersz Baczyńskiego ${ }^{8}$.

rg.ru/2016/o2/29/perevodchik-grigorij-kruzhkov-bez-svoej-krovi-nichego-ne-poluchitsia.html (dostęp I5.04.202I).

5 Г. Кружков, Сон о Польме (1995-1997), [w:] Г. Кружков, Бирнамский лес. Избранные стихи и проза, Русский Міръ, Москва 2020, s. 53-54. Mówiąc w innym miejscu o tłumaczeniach Pasternaka, sięga Krużkow do szczegółów utworu Leśmiana Do siostry. Por. Г. Кружков, Ностальгия обелисков. Литературные мечтания, URL: http://www.vavilon.ru/texts/prim/kruzhkov3-I8.html (dostęp I5.04.202I).

6 Krużkow wspomina, jak Brodski spontanicznie śpiewał Czerwone maki przy akompaniamencie fortepianu w założonej przy jego wsparciu, wspólnie z Michaiłem Barysznikowem, kawiarni „Russian Samovar” w Nowym Jorku. Por. I. Grudzińska-Gross, Kruche tradycje, URL: https:// wydawnictwoproby.pl/kruche-tradycje/ (dostęp I0.05.202I).

7 Borys Dubin (1946-2014), socjolog, zajmujący się problemami regionalności, peryferyjności w kulturze. Uważał za swe wielkie szczęście, iż była mu dana możliwość przekładu polskiej literatury XX wieku. Por. URL: https://godliteratury.ru/articles/2018/o9/o4/boris-dubin-vysokiy-perevod (dostęp I. 05. 202I). Borys Dubin brał udział w 2012 roku w prezentacji książki Grigorija Krużkowa Луна и дискобол w RGGU.Zob. URL: https://www.youtube.com/watch?v=AıU8mVI2gik (dostęp I.06.202I). Spotkanie to otwierał inny polonofil, Dmitrij Bak, z którym wspólnie recytowaliśmy kiedyś na Patriarszych Prudach Stepy akermańskie - a znał je całe po polsku!

8 Центр чтения Российской Национальной Библиотеки, Книжная полка Никиты Елисеева. Выпуск 5. URL: http://nlr.ru/prof/reader/poleznlink/elektronnye-biblioteki/2-uncategorised/ror74deyatelnost-proekty-kp-eliseeva-vyp-5 (dostęp I2.06.202I). Cieszy fakt, że poezja Baczyńskiego 
Ogrom wykonanych przez Krużkowa prac tłumaczeniowych, szeroki krąg jego poetyckich upodobań oraz tworzenie równolegle subtelnych komentarzy przekładoznawczych - przywodzi na myśl podobną skalę dokonań na polskim gruncie Stanisława Barańczaka. Nie sposób nie zauważyć, że obaj odznaczają się też niespotykaną wynalazczością językową i niezwykłym poczuciem humoru. Krużkow daje temu wyraz przede wszystkim jako autor literatury dla dzieci oraz tłumacz limeryków, zwłaszcza Edwarda Leara. Napisał też pełen humoru wiersz, utrzymany w poetyce snu, który pokazuje niełatwą sytuację tłumacza Yeatsa. Przedstawił tam siebie jako tego, kto - nie bez lęku - zaczął wysiadywać pozostawione przez orła jaja, aż wykluły mu się z nich małe „jejtsiki” (ros. „ейцки”) ${ }^{9}$. Dodajmy, że i w tej żartobliwej formie Krużkow jeszcze raz wskazuje, jak wielkiej potrzeba cierpliwości i determinacji, aby osiągnąć prawdziwą wspólnotę ducha autora i tłumacza. Bo to ona jest warunkiem powołania do życia wartościowych przekładów. Warto podkreślić, że opinię o równorzędnej kulturowo roli tłumacza i autora wyrażają równie dobitnie Olga Tokarczuk i Wiesław Myśliwski. Ten ostatni, na Gdańskich Spotkaniach Tłumaczy Literatury „Odnalezione w tłumaczeniu” w 2017 roku, z udziałem Billa Johnstona, Karola Lesmana, Margot Carlier, Kseni Starosielskiej, powiedział wprost:

Zdawałem sobie sprawę, że jeśli tłumacz „bierze” mój tekst, to ma prawo stworzyć swoją książkę. Uważam, o czym wielokrotnie mówiłem, że tłumacz jest w gruncie rzeczy współtwórcą książki. W Polsce pojęcie tłumaczenia używane jest w wielu kontekstach: o tłumaczu przysięgłym mówimy - tłumacz i o tłumaczu literatury pięknej również mówimy - tłumacz. A autor ${ }^{10}$ literatury pięknej (tzn. tej będącej przekładem - przyp. L. S-P) nie jest tłumaczem - jest współtwórcą książki w swoim

jest dziś obecna na stronie Państwowej Biblioteki w Petersburgu. Z właściwą bibliografowi dokładnością Jelisiejew odnotowuje datę powstania wiersza - listopad I94I, jak i fakt, że został on wydany w antologii podziemnej poezji Miłosza. Przytoczone zostają fragmenty utworu w przekładzie Borysa Dubina, który zaczyna się od słów: „Господь улыбнулся - и встала земля звездою, / как зеркало многоликой, как яблоко золотою”, a kończy mocną frazą: „Усталый Бог улыбнулся и вновь погрузился в дрёму, / а тёмному человеку скитаться от грома к грому”. Działalność popularyzatorska Jelisiejewa i rozmach inicjowanych dziś przez niego akcji „Czytajmy Razem” oraz „Bieg Intelektualny: Biegiem za ksiażka” - budzą szacunek i podziw.

9 Г. Кружков, Сон, записанный на обороте перевода У.Б. Йейтса [w:] Г. Кружков, Бумеранг. Третья книга стихов http://www.vavilon.ru/texts/prim/kruzhkovi-2.html\#4 (dostęp I5.04.202I). Neologizm „ейцки” jest czytelny tylko na gruncie słowiańszczyzny (z uwagi na zbieżność wymowy nazwiska W.B. Yeatsa, w dopełniaczu, z polskim augmentativum słowa ,jajka” - ros. яйца). Nasuwa się tutaj pewna analogia do wiersza Nabokova On Translating „Eugene Onegin”, gdzie z kolei przekład porównany jest do pieśni kukułczego pisklęcia. Skądinąd wiemy, że autor ten uważał swoje, kontrowersyjne dla wielu, tłumaczenie Eugeniusza Oniegina za jedynie możliwe metodologicznie. Więcej o tym: L. Styrcz-Przebinda, Stowiańskość w zachodnim świecie. Nabokov-wieczny ttumacz, [w:] Komunikacja międzykulturowa w świetle wspótczesnej translatologii, red. E. Kujawska-Lis, I. A. Ndiaye, t. I, Katedra Filologii Angielskiej UWM w Olsztynie, Olsztyn 2014, s. 97, IO3.

10 Myśliwski nazywa więc tutaj tłumacza literatury pięknej autorem, podzielając tym samym w pełni opinię Krużkowa wyrażoną w jego eseju Stworzyć czy odtworzyć? O nowych przektadach Eugeniusza Oniegina. 
języku. [...] To jest jego święte prawo, żeby on tę książkę stworzył, STWORZYŁ, nie przetłumaczył - stworzył we własnym języku ${ }^{11}$.

O tym właśnie traktują, poczynając od czasów starożytności, przedstawiane tu eseje Grigorija Krużkowa: Przektad a mechanika kwantowa, Przektad i Eros oraz Przektad a nieśmiertelność. Autor nie szczędzi w nich przykładów translatorskiego trudu wielu autorów. Cytuje frazy Katullusa, Safony, Burnsa, Szekspira, Donne’a, Blake’a, Yeatsa, Gravesa, Hugo, aby unaocznić nam, że tylko prawdziwy tłumacz współtwórca stanowi dla wielkiego autora gwarancję nieśmiertelności.

\section{Bibliografia}

Balla-Gertman O., Grigoriy Kruzhkov. Perevod yest' stremleniye okonchatel'no ponyat', URL: http://textura.club/perevod-est-stremlenie-okonchatelno-ponyat/ (dostęp 25.06.202I).

Basinskiy P., Perevodchik Grigoriy Kruzhkov rasskazal ob osobennostyakh svoyey professii, URL: https://rg.ru/20I6/o2/29/perevodchik-grigorij-kruzhkov-bez-svoej-krovi-nichego-ne-poluchitsia.html (dostęp I5.04.202I).

Grudzińska-Gross I, Kruche tradycje, URL: https://wydawnictwoproby.pl/kruche-tradycje/ (dostęp I0.05.202I).

Kruzhkov G., 2012, Luna i diskobol. O poezii i poeticheskom perevode, Izdatel'stvo RGGU, Moskva.

Kruzhkov G., 2020, Сон о Польmе (I995-1997), [w:] Kruzhkov G., Birnamskiy les. Izbrannye stikhi i proza, Russkiy Mir, Moskva.

Kruzhkov G., Son, zapisannyy na oborote perevoda U.B. Yyeytsa, [w:] Kruzhkov G., Bumerang. Tret'ya kniga stikhov, URL: http://www.vavilon.ru/texts/prim/kruzhkovi-2.html\#4 (dostęp I.06.202I).

11 Wojewódzka Biblioteka im. Witolda Gombrowicza w Kielcach. Twórczość Wiesława Myśliwskiego w przekładach. Wystawa ze zbiorów Wojewódzkiej Biblioteki Publicznej im. Witolda Gombrowicza w Kielcach, Instytutu Książki w Krakowie, Biblioteki Narodowej w Warszawie, Biblioteki Śląskiej w Katowicach. URL: http://sbc.wbp.kielce.pl/Content/42860/Tw\% $\mathrm{C}_{3} \% \mathrm{~B}_{3} \mathrm{rczo} \%{ }_{5}{ }_{5}{ }_{9} \mathrm{Bc}$ Wies\%C5\%82awa_Mysliwskiego.pdf (dostęp I5.04.202I). Znamienne są słowa z listu Myśliwskiego do jego tłumacza Billa Johnstona: „Uzmysłowiłem sobie wówczas, że sztuka przekładu musi sięgać korzeniami ducha języka, jeśli chce być sztuką. Że rodzi się ona nie tylko z umiejętności, leczi z miłości, jak w ogóle sztuka. [...] Jeśli chodzi o moje książki w Pańskim tłumaczeniu, to powiedziałem Panu kiedyś, a może napisałem, że jest Pan ich współtwórcą w języku amerykańsko-angielskim. Nie tłumaczem - to zbyt banalne, nie wyraża istoty rzeczy - lecz właśnie współtwórcą”. Tamże. Warto dodać, że Bill Johnston, mający wielkie zasługi w popularyzacji polskiej literatury - począwszy od Kochanowskiego, Mickiewicza, Słowackiego - został w 20I4 roku laureatem Nagrody Transatlantyk, właśnie za przekład prozy Myśliwskiego. Natomiast w 2019 roku otrzymał National Translation Award za nowe tłumaczenie Pana Tadeusza. 
Krużkow G. 20I7, Przektad i Eros. Przektad a nieśmiertelność, „Przekładaniec”. A Journal of Translation Studies, nr 35.

Styrcz-Przebinda L., 20I4, Stowiańskość w zachodnim świecie. Nabokov - wieczny ttumacz, [w:] Komunikacja międzykulturowa w świetle wspótczesnej translatologii, red. E. Kujawska-Lis, I. A. Ndiaye, t. I, Katedra Filologii Angielskiej UWM w Olsztynie, Olsztyn.

Tsentr chteniya Rossiyskoy Natsional'noy Biblioteki, knizhnaya polka Nikity Yeliseyeva, Vypusk 5, URL: http://nlr.ru/prof/reader/poleznlink/elektronnye-biblioteki/2-uncategorised/ IOI74-deyatelnost-proekty-kp-eliseeva-vyp-5 (dostęp I.06.202I).

Twórczość Wiesława Myśliwskiego w przekładach. Wystawa ze zbiorów Wojewódzkiej Biblioteki Publicznej im. Witolda Gombrowicza w Kielcach, Instytutu Książki w Krakowie, Biblioteki Narodowej w Warszawie, Biblioteki Śląskiej w Katowicach. URL: http://sbc.wbp. kielce.pl/Content/42860/Tw\%C3\%B3rczo\%C5\%9Bc_Wies\%C5\%82awa_Mysliwskiego.pdf (dostęp I.06.202I).

STRESZCZENIE

Grigorij Krużkow - poezji anglojezycznej ttumacz niestrudzony

Twórczość Grigorija Krużkowa jest ze wszech miar godna opisu i popularyzacji. To ceniony i nagradzany rosyjski tłumacz poezji anglojęzycznej, teoretyk przekładu, profesor w Katedrze Teorii i Praktyki Przekładu Rosyjskiego Państwowego Uniwersytetu Humanistycznego w Moskwie. Jest m.in. autorem obszernej antologii przekładów IIs angielskich, irlandzkich i amerykańskich poetów oraz wyboru angielskich i irlandzkich wierszy i bajek. W 2015 roku otrzymał tytuł doktora honoris causa Trinity College w Dublinie. Widzi on pracę tłumacza jako twórczość, która rodząc się z miłości i jedności duchowej z autorem oryginału, może zapewnić temu ostatniemu nieśmiertelność w innych językach. Do tego właśnie nawiązują wyraźnie tytuły jego esejów. Co ciekawe, na polskim gruncie analogiczne wnioski formułuje z wielkim przekonaniem Wiesław Myśliwski, podkreślając, że tłumacz musi stworzyć (nie odtworzyć) dzieło na nowo we własnym języku.

\section{SŁOWA KLUCZOWE}

Krużkow jako tłumacz poezji anglojęzycznej, Krużkow jako teoretyk przekładu, związki Krużkowa z Polską, jedność duchowa autora i tłumacza, tłumacz jako współautor.

\section{ABSTRACT}

\section{Grigory Kruzhkov - A Tireless Translator of English-Language Poetry}

The work of Grigory Kruzhkov is by all means worth describing and popularizing. He is a respected and awarded Russian translator of English-language poetry, translation theorist, professor at the Department of Russian Translation Theory and Practice of the Russian State 
University for the Humanities. He is, among others, the author of an extensive anthology of translations of is 5 English, Irish and American poets and a selection of English and Irish poems and fairy tales. In 20I5, he was awarded an honorary doctorate from Trinity College in Dublin. He sees the translator's work as creativity which - born out of love and spiritual unity with the author of the original - can grant the latter immortality in other languages. This is what the titles of his essays clearly allude to. Interestingly, in Poland, similar conclusions are formulated with great conviction by Wiesław Myśliwski, stressing that the translator must create (not recreate) the work in his own language.

\section{KEY WORDS}

Kruzhkov as a translator of English-language poetry, Kruzhkov as a theoretician of translation,Kruzhkov's ties with Poland, spiritual unity of the author and translator, translator as co-author. 